\title{
Nilai Estetis Pada Kemasan Makanan Tradisional Yogyakarta
}

\author{
Setiawan Sabana \\ KK Senirupa-Fakultas Senirupa dan Desain ITB
}

\begin{abstract}
This research is focused on investigating the aesthetical and philosophical values of traditional food packaging in Yogyakarta, whereas much of traditional values are still applied and existed in the daily life.

It is thought that the philosophical value of traditional food packaging is related to its use in the traditional ceremonies of the Yogyakarta Palace, such as Garebeg Mulud (Sekaten), Garebeg Syawal, Garebeg Idhul Adha, Tumplak Wajik, and Labuhan. Although some of traditional food packaging are also used in the people's ceremony, such as birth, wedding, and funeral ceremonies. Accordingly, traditional food packagings are mostly used to represent symbols that link to the life of the people of Yogyakarta.

The aesthetical value of traditional food packaging can be identified from its visual elements, such as shapes, lines, textures, colors, masses (volumes), spaces, and the composition of those elements using natural materials such banana leaf and young coconut leaf. The intertwined of each element carry on meanings and therefore when modern materials (papers and plastics) are applied, most of traditional food packaging degrades their actual and symbolical meanings.
\end{abstract}

Keywords: traditional food packaging; aesthetics value; philosophic.

\section{Pendahuluan}

Indonesia memiliki keragaman budaya sebagai akibat dari keragaman suku bangsa yang mendiami kawasan ini. Budaya tersebut mencakup sistem teknologi tradisional, adat istiadat, dan sebagainya. Di antara keragaman itu, salah satu hasil budaya yang menarik adalah keragaman jenis makanan tradisional yang berhubungan erat dengan teknologi pengolahan bahan dalam proses pembuatan kemasan maupun proses memasak makanan tradisional.

Seluruh suku di Indonesia memiliki kekhasan dalam jenis, teknologi, dan kemasan makanan tradisional. Keberadaan makanan tradisional itu pada umumnya tidak terlepas dari adat istiadat suatu masyarakat tertentu. Sehingga makanan tradisional dapat menjadi cerminan budaya suatu masyarakat.

Received December $6^{\text {th }} 2006$, Revised February $5^{\text {th }} 2007$, Accepted for publication March $5^{\text {th }} 2007$. 
Dalam masyarakat Yogyakarta yang masih mempertahankan kepemimpinan Sultan sebagai Kepala Daerah, berbagai tradisi mengemas makanan terbagi dalam kegiatan aktifitas keseharian Sultan, kegiatan upacara Kasultanan, kegiatan upacara masyarakat pada masyarakat umumnya, dan kemasan makanan sehari-hari.

Tulisan ini memaparkan kemasan makanan yang digunakan oleh masyarakat Yogyakarta, mencakup keempat pembagian di atas untuk mengetahui nilai estetis dan filosofis yang terkandung dalam kemasan makanan tersebut.

\section{$2 \quad$ Makanan Tradisional}

Kegiatan makan seringkali dianggap sebagai kegiatan pemenuhan kebutuhan dasar semata, padahal dari sudut kajian antropologi budaya, kegiatan makan merupakan suatu bagian dari tujuh unsur kebudayaan. Setiap kebudayaan memiliki kekhasan tersendiri dalam kegiatan makan, mulai dari menyiapkan bahan makanan, proses memasak, mengemas, hingga proses memakannya.

Tjetjep Rohendi mengungkapkan tentang perspektif antropologi dalam memandang budaya makan, tertulis dalam paparan Kemasan Tradisional Makanan Sunda Bahasan dalam Perspektif Antropologi Budaya, 2001:

Dalam perspektif antropologi, khususnya budaya, makanan bukanlah sesuatu yang dipandang semata-mata berhubungan dengan aspek fisiologis dan biologis manusia melainkan secara menyeluruh terserap dalam suatu sistem budaya makanan. Sistem budaya makanan mencakup kegiatan produksi, distribusi, dan konsumsi makanan yang di dalamnya tersirat pemenuhan kebutuhan manusia- -primer, sosial, dan budaya- dalam rangka melangsungkan kehidupan dan meningkatkan kesejahteraan diri, keluarga, dan masyarakatnya, dihadapkan pada sumber daya lingkungan alam (juga sosial-budaya) yang dapat dimanfaatkannya.

Makanan tradisional adalah makanan yang telah membudaya di kalangan masyarakat Indonesia, serta telah ada sejak nenek moyang suku nusantara (Muhilal, 1995). Menurut Winarno (1993), makanan tradisional adalah makanan yang pekat dengan tradisi setempat. Sementara itu Hadisantosa (1993), mendefinisikan pangan tradisional sebagai makanan yang dikonsumsi oleh golongaan etnik dan wilayah spesifik, diolah berdasarkan resep yang secara turun temurun. Bahan yang digunakan berasal dari daerah setempat dan makanan yang dihasilkan juga sesuai dengan selera masyarakat. 


\section{$3 \quad$ Nilai Estetis Kemasan Makanan Tradisional}

Setiap manusia memiliki rasa keindahan. Keindahan tersebut tidak terbatas pada keinginan memperindah ruangan dengan sebuah lukisan pemandangan, rasa keindahan itu diekspresikan dalam berbagai hal dalam kehidupan. Misalnya dalam menentukan jenis pakaian, bentuk mobil, bahkan perlengkapan rumah tangga pun setiap manusia mempertimbangkan pilihan dengan rasa keindahan yang dimilikinya. Keindahan itu biasa dikenal dengan istilah nilai estetis.

Berdasarkan Kamus Besar Bahasa Indonesia pengertian estetis berarti sesuatu yang indah; mengenai keindahan; tentang apresiasi keindahan yang berhubungan dengan alam, seni, dan sastra. Arti lainnya yaitu mempunyai penilaian terhadap keindahan. Sedangkan pengertian estetika berdasarkan Kamus Besar Bahasa Indonesia adalah cabang filsafat yang menelaah dan membahas tentang seni dan keindahan serta tanggapan manusia terhadapnya, pengertian lain tentang keindahan yaitu kepekaan terhadap seni dan keindahan.

Dikaitkan dengan pembahasan mengenai kemasan tradisional, nilai estetis yang terkandung dalam kemasan tradisional tersebut tidak sebatas muncul dari keindahan bentuknya, pengertian nilai estetisnya dapat menjadi luas, misalnya nilai estetis yang hadir justru dari unsur budaya teradat atau nilai tradisi dari bentuk kemasan makanan tersebut.

Pemaparan selanjutnya berkaitan dengan pengertian kemasan. Kemasan berasal dari kata kemas yang berarti teratur (terbungkus) rapi; bersih; rapi; beres; selesai. Pengertian kemasan lainnya merupakan hasil mengemas atau bungkus pelindung dagangan (niaga). Sedangkan pengertian bungkus dapat diartikan sebagai kata bantu bilangan untuk benda yang dibalut dengan kertas (daun, plastik, dan sebagainya); pengertian lainnya barang apa yang dipakai untuk membalut. Dengan demikian dalam tulisan ini pengertian kemasan adalah sesuatu (material) dapat berupa daun, kertas, maupun plastik yang digunakan untuk membungkus makanan.

Secara keseluruhan pengertian kemasan makanan tradisional berdasarkan uraian-uraian di atas adalah sesuatu (material) dapat berupa daun, bambu, atau pelepah (produk-produk tradisional) yang biasa digunakan untuk mengemas atau membungkus makanan. Teknik pengemasan tersebut dilakukan secara tradisional. Sedangkan nilai estetis sebuah kemasan makanan dapat dilihat dari sisi rupa kemasan tersebut. Rupa dari sebuah kemasan mengandung unsur-unsur rupa antara lain bentuk, garis, tekstur, warna, ukuran (mass), bidang (space), juga terdapat pertimbangan mengatur komposisi dari berbagai unsur tadi dalam sebuah wujud. 
Nilai tradisi atau nilai filosofi dari sebuah kemasan, misalnya pada kemasan ketupat merupakan salah satu unsur nilai keindahan karena dengan melihat kemasan tersebut dapat menggugah perasaan orang kepada tradisi pembuatan ketupat pada hari Idul Fitri. Nilai estetisnya muncul bukan dari segi rupa saja melainkan dari sisi tradisi yang dikandungnya yang dapat membangkitkan ingatan seseorang pada kereligiusan hari Idul fitri .

\section{Kemasan Makanan Tradisional dalam Upacara Kasultanan Yogyakarta}

Daerah Istimewa Yogyakarta merupakan wilayahl tempat Kraton Yogyakarta berada. Wilayah Yogyakarta seluas 3.185,81 Km, terdiri dari wilayah pedesaan (pemukiman, tanah persawahan (62.370 Ha), tanah tegalan (109.630 Ha), hutan dan perkebunan, dan sekitar 30.000 Ha tanah kritis.

Daerah Istimewa Yogyakarta terletak pada posisi $7.30^{\prime}$ - 8.15’ garis lintang Selatan dan 110 - 110.15' bujur Timur. Wilayah ini dikelilingi oleh wilayah Jawa Tengah yaitu Kabupaten Purworejo di Barat, Kabupaten Magelang di Utara, dan Kabupaten Klaten di Timur) kecuali di bagian Selatan dibatasi oleh Samudra Indonesia.

Keraton Yogyakarta masih mempertahankan berbagai upacara tradisi yang diyakini dapat melindungi masyarakatnya. Berbagai upacara tersebut seperti upacara Garebeg Maulud dan Upacara Labuhan. Dalam aktifitas keseharian masyarakat Yogyakarta secara luas masih mempertahankan tradisi, seperti aktifitas yang berkaitan dengan siklus hidup seperti kelahiran, kematian, pernikahan, selalu diiringi dengan berbagai upacara. Dalam pelaksanan upacara tersebut selain atribut, pakaian juga terdapat makanan tradisional yang berfungsi sebagai sesaji.

Upacara-upacara yang diselenggarakan oleh Keraton Yogyakarta lainnya yang terdapat unsur makanan saji ,antara lain upacara Sekaten (Garebeg Mulud), Garebeg Syawal, Garebeg Idhul Adha, Tumplak Wajik, dan Labuhan ${ }^{[10]}$.

\subsection{Upacara Garebeg}

Upacara sesaji garebeg dimaksudkan untuk mempersatukan seluruh kelas sosial yang ada dalam masyarakat Yogya, mulai dari Sultan, abdi dalem hingga masyarakat kebanyakan. Kumpulan makanan sebagai sesaji tersebut berbentuk gunungan tersebut diyakini dapat melindungi diri dari kemalangan dan roh jahat. 
Upacara garebeg yang diadakan tiga kali dalam setahun dan diperkirakan telah ada sejak masa pemerintahan Hamengku Buwono I. Upacara tersebut bertujuan untuk memperingati kelahiran Nabi Muhammad S.A.W., hari Idul Fitri, dan hari Idul Adha. Upacara ini kemudian dikenal dengan istilah Sekaten (Garebeg Mulud), Garebeg Syawal, dan Garebeg Idul Adha. Kemudian dikenal sebagai Garebeg Sekaten (Garebeg Mulud), Garebeg Syawal, dan Garebeg Idul Adha. Dalam rangkaian kegiatan upacara garebeg itu diselenggarakan pula upacara Tumplak Wajik.

Upacara Sekaten (Garebeg Mulud) berlangsung pada tanggal 5 bulan Maulud untuk memperingati hari kelahiran Nabi Muhammad S.A.W. yang merupakan Nabi umat Islam. Masyarakat percaya bahwa dengan merayakan upacara ini akan menjamin keselamatan dan kesehatan di masa yang akan datang. Gunungan yang mengiringi upacara tersebut dibuat dari hasil bumi masyarakat Yogyakarta yang dibagikan oleh Keraton.

Sedangkan upacara Tumplak Wajik merupakan upacara yang dilakukan sebelum kegiatan upacara Garebeg dilangsungkan, yaitu pada pukul empat sore, dua hari sebelum upacara Garebeg dilaksanakan.

Terdapat enam jenis Gunungan yang biasa ditampilkan dalam upacara Garebeg yaitu Gunungan Lanang, Gunungan Wadon, Gunungan Gepak, Gunungan Pawuhan, Gunungan Darat, dan Gunungan Kutug atau Bromo.

Makanan yang digunakan sebagai komponen gunungan terdiri dari beragam jenis kue dan hasil pertanian. Jenis makanan tersebut adalah kucu, upil-upil, tlapukan, rengginan, sabunan, tedheng, eblek, bethetan, ilat-ilatan, ole-ole, badheran, bendhul, sangsangan, dhengul, pelokan, tangkil kacang, cabai merah, cabai hijau.

Terdapat enam jenis gunungan untuk upacara Garebeg Mulud yang keluar pada tanggal 12 Rabiulawal, yaitu dua buah Gunungan Lanang, sebuah Gunungan Wadon, sebuah Gunungan Gepak, sebuah Gunungan Pawuhan. Untuk Garebeg Mulud Dal yang diadakan 8 tahun sekali bertepatan dengan tahun Dal, jenis gunungannya ditambah satu yaitu Gunungan Bromo atau Gunungan Kutug. Pada Garebeg Syawal yang dikeluarkan hanya Gunungan Lanang. Jenis Gunungan untuk untuk Garebeg Besar (Idul Adha) serupa dengan jenis Gunungan Mulud.

Berdasarkan penuturan Darsiti Soeratman [10] makna perlambangan Gunungan Grebeg: 
Pertama bentuknya yang menyerupai gunung menunjuk nilai kesakralan yaitu mengingatkan kita pada candi atau punden berundak-undak sebagai tempat para dewa atau roh nenek moyang bersemayam. Makna kedua masyarakat yang masih dilekati adat lama Jawa, hajat dalem unungan merupakan bentuk persembahan kurban yang mempunyai kekuatan magis. Makna ketiga wujud gunungan yang terdiri atas buah-buahan, sayuran, telur, makanan dari beras dan ketan ditambah dengan masakan dari bahan daging beranalogi dengan penertian pohon hayat, melambangkan kemakmuran atau kehidupan itu sendiri. Makna keempat penamaan Gunungan Lanang dan Wadon adalah penerapan klasifikasi dualisme yang saling melengkapi.

Makna lain berkaitan dengan perlambangan Gunungan Grebeg diungkapkan oleh Koentjaraningrat ${ }^{[10]}$ :

Melalui bentuk gunungan yan berupa kerucut yang dibawa ke Masjid Agung untuk diberi doa secara Islam oleh seorang penghulu, selain menandakan adanya sinkretisme dalam kehidupan keagamaan di kraton, juga menandakan bahwa selamatan kerajaan (wilujengan nagari) oleh Sultan sangat bermanfaat untuk menjaga keseimbangan dan keselarasan kehidupan masyarakat sepanjang masa. Selamatan, kenduri, atau makan bersama ini merupakan unsur yang penting dalam upacara adat dari banyak agama di dunia, yang dasar pemikirannya adalah mencari hubungan dengan para dewa dengan cara mengundang dewa pada pertemuan makan bersama.

Gunungan Grebeg tersebut disiapkan di Istana (Sithinggil) dan dibawa ke Masjid Agung di sisi barat alun-alun dalam upacara besar disaksikan semua lapisan masyarakat.

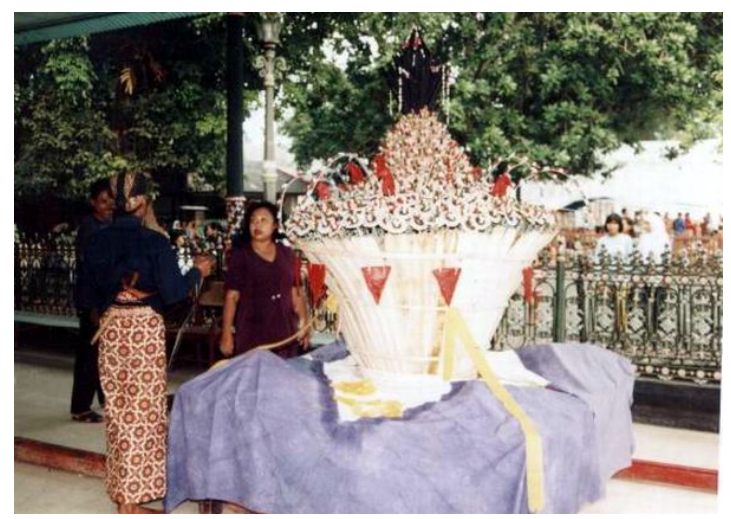

Gambar 1 Gunungan Wadon saat diletakkan dalam lingkungan keraton. 


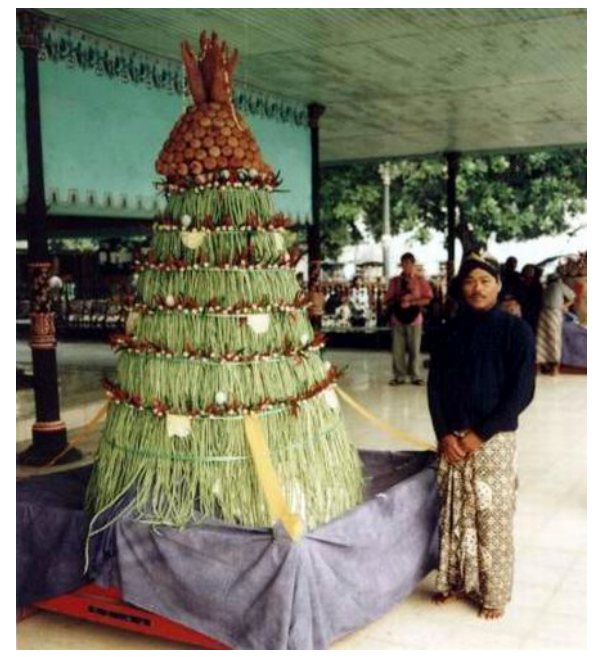

Gambar 2 Gunungan Lanang dalam Jodhangan.

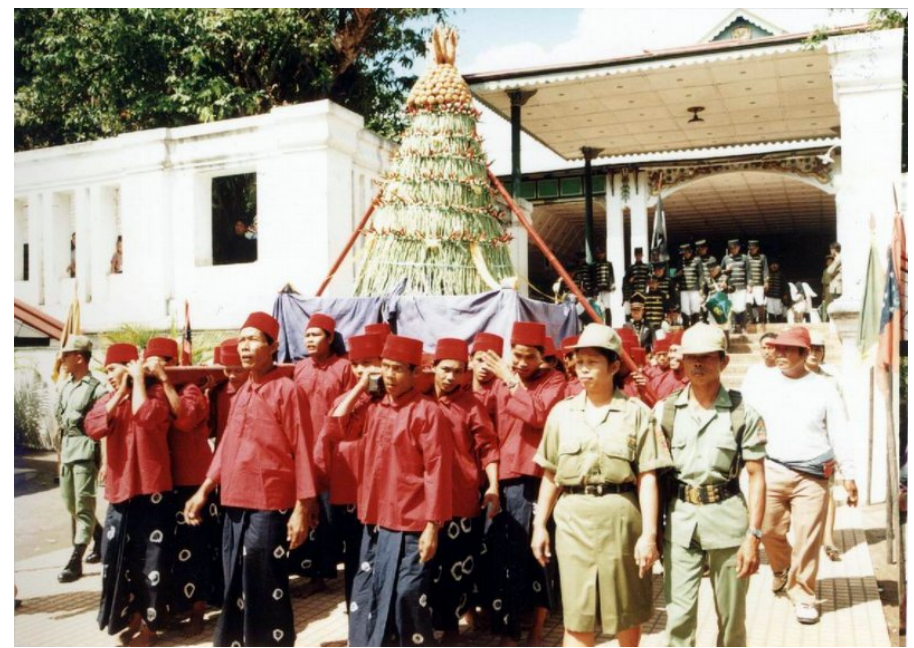

Gambar 3 Gunungan Lanang saat meninggalkan Sitihinggil.

\subsection{Upacara Labuhan}

Upacara Labuhan merupakan upacara untuk memperingati kelahiran Sri Sultan Hamengku Buwono. Labuhan merupakan upacara yang dilakukan di sungai atau di laut. Upacara ini berlangsung di Pantai Selatan, Gunung Merapi dan di Gunung Lawu. Upacara bertujuan supaya Raja dan rakyatnya memperoleh kesehatan. 
Upacara Labuhan ini berkaitan dengan konsep kekuasaan tradisional yang umumnya percaya akan kekuatan gaib dan roh para leluhur yang bersemayam di puncak gunung maupun hubungan mistis antara para Raja Mataram dengan Nyi Roro Kidul.

\section{$5 \quad$ Kemasan Makanan pada Upacara Tradisi Masyarakat Yogya}

Nilai-nilai dan norma-norma kehidupan yang tumbuh di dalam masyarakat Jawa bertujuan untuk mencari keseimbangan dalam tatanan kehidupan. Nilai-nilai dan norma-norma itu berkembang sejalan dengan dinamika kebudayaan masyarakat setempat, yang akhirnya lambat laun tumbuh menjadi adat istiadat.

Kegiatan upacara yang berkaitan dengan siklus hidup manusia dalam lingkungan Keraton Yogyakarta antara lain upacara 'Selamatan' bagi perempuan yang sedang hamil, 'Selamatan' bagi bayi mencakup: 'Selamatan Bayi Menurut Hari Kelahirannya', 'Selamatan Menyambut Kelahiran Bayi', 'Selamatan Sepasaran', 'Selamatan Puputan', dan 'Upacara Tedak Siten'. Jenis selamatan lainnya adalah 'Selamatan Khitanan' (Tetekan), dan juga pelbagai bentuk upacara antara lain Upacara Ruwatan, dan Upacara Pernikahan.

Di bawah ini adalah gambar-gambar dari bentuk sesajen yang biasa digunakan oleh masyarakat Yogyakarta di lingkungan Kraton maupun di Lingkungan luar Kraton. Bentuk sesajen di bawah ini berkaitan dengan upacara siklus hidup.

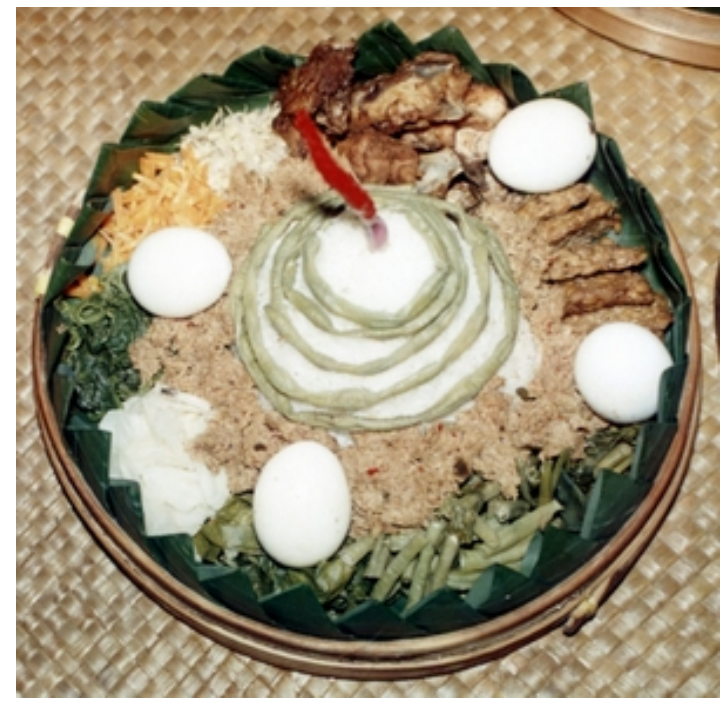

Gambar 4 Sajen Tumpeng Megana. 


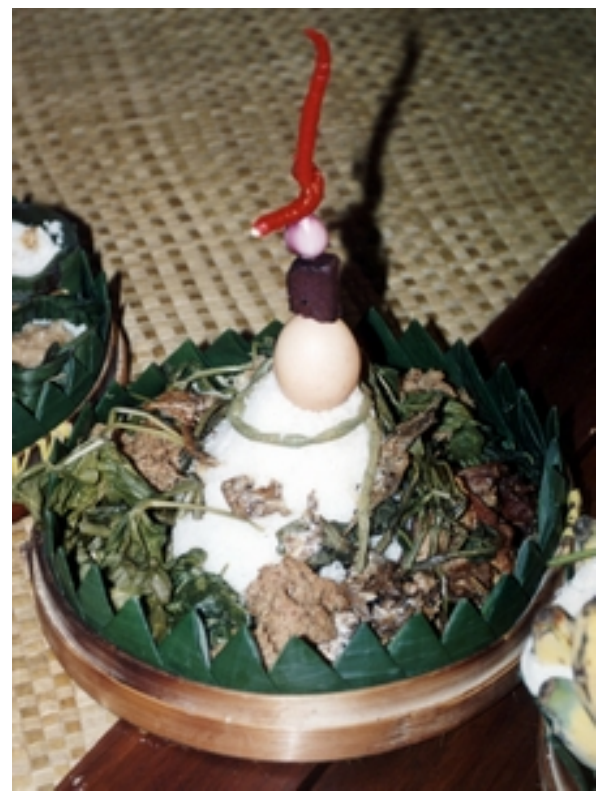

Gambar 5 Sajen Tumpeng Robyong.

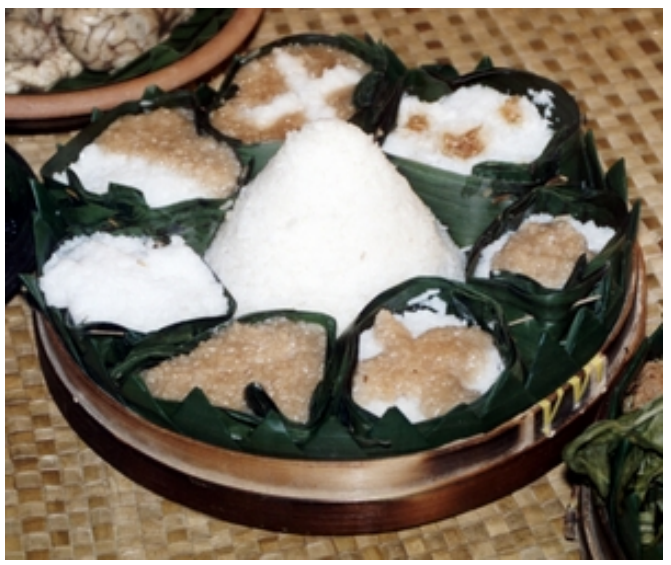

Gambar 6 Sajen Tumpeng Gundhul.

Hakikatnya tidak terdapat perbedaan yang jauh antara jenis makanan yang disajikan di lingkungan keraton, maupun jenis makanan yang ada di masyarakat kebanyakan. Masyarakat Yogyakarta menurut Moertjipto (1994) mengklasifikasikan makanan menjadi beberapa kelompok, yaitu jenis makanan pokok, makanan sambilan, makanan jajanan, makanan untuk peristiwa khusus, dan jenis makanan untuk upacara. Pengembangan dari pendapat Moertjipto 
jenis makanan lain yang melengkapi makanan pokok adalah lauk pauk dan sayur yang dikonsumsi bersamaan dengan makanan pokok.

Makanan pokok masyarakat Yogyakarta adalah nasi yang berasal dari beras, terdapat pula jenis bahan makanan lain yang prinsipnya bersifat mengenyangkan seperti ketela dan jagung. Berdasarkan bahan dan cara memasaknya, makanan pokok di Yogyakarta terdiri dari:

1. Makanan pokok bahan dari beras berupa nasi liwet, nasi tim, nasi kukus/segodang, dan nasi bubur.

2. Makanan pokok dari bahan ketela berupa nasi thiwul, gogik, dan growol.

3. Makanan pokok dari bahan jagung berupa nasi jagung/bongkel dan bubur jagung.

Berbagai makanan pokok di atas terdapat jenis makanan pokok yang biasa dimakan oleh masyarakat atas atau priyayi maupun masyarakat lapisan bawah. Saat ini pembagian kelas masyarakat Yogyakarta dapat berdasarkan taraf ekonomi mereka. Jenis makanan yang biasa dikonsumsi masyarakat kelas bawah adalah growol, thiwul, gogik, dan nasi jagung.

Jenis makanan sambilan dalam masyarakat Yogyakarta adalah makanan yang berfungsi sebagai selingan makanan pokok atau disebut juga dengan istilah makanan samberan atau emlik-emlik. Bahan makanan jenis ini dapat berasal dari ubi-ubian, talas, ganyong dan alin sebagainya.

Makanan jenis lainnya adalah makanan jajanan adalah jenis makanan yang digunakan sebagai makanan selingan atau hiburan yang dapat dimakan setiap saat diantara waktu makan pokok. Umumnya hanya kelas atas atau golongan masyarakat mampu yang dapat menyediakan makanan jajanan. Makanan ini biasanya diperoleh dengan membeli/jajan.

Makanan untuk peristiwa khusus berkaitan dengan untuk kenikmatan dalam aktifitas bersama seperti gotong royong atau piknik. Jenis makanan tersebut seperti arem-arem, jadah tempe, ketela bakar, dan lain sebagainya.

Tabel 1 Jenis Kemasan Makanan dalam Kelompok Makanan Pokok.

\begin{tabular}{|l|l|l|l|l|}
\hline No. & $\begin{array}{l}\text { Nama } \\
\text { Kemasan }\end{array}$ & Nama Makanan & $\begin{array}{l}\text { Bahan \& Teknik } \\
\text { Kemasan }\end{array}$ & $\begin{array}{l}\text { Bahan } \\
\text { Makanan }\end{array}$ \\
\hline 1. & Pincuk & $\begin{array}{l}\text { Bubur Saren (bor } \\
\text { soren) }\end{array}$ & $\begin{array}{l}\text { Daun pisang } \\
\text { /Lipat/tum }\end{array}$ & $\begin{array}{l}\text { Tepung } \\
\text { Sagu }\end{array}$ \\
\hline 2. & Pincuk & Mendut Ketan & $\begin{array}{l}\text { Daun pisang /Lipat } \\
\text { kerucut }\end{array}$ & $\begin{array}{l}\text { Tepung } \\
\text { Ketan }\end{array}$ \\
\hline
\end{tabular}




\begin{tabular}{|c|c|c|c|c|}
\hline No. & $\begin{array}{l}\text { Nama } \\
\text { Kemasan }\end{array}$ & Nama Makanan & $\begin{array}{l}\text { Bahan \& Teknik } \\
\text { Kemasan }\end{array}$ & $\begin{array}{l}\text { Bahan } \\
\text { Makanan }\end{array}$ \\
\hline 3. & Pincuk & Tiwul & $\begin{array}{l}\text { Daun pisang \& } \\
\text { kertas /Lipat/tum }\end{array}$ & Ketela \\
\hline 4. & Pincuk & Moto Kebo & $\begin{array}{l}\text { Daun pisang } \\
\text { /Lipat/tum }\end{array}$ & Beras Ketan \\
\hline 5. & Bungkus & Grontol & $\begin{array}{l}\text { Daun Pisang, } \\
\text { biting/ Bungkus }\end{array}$ & Jagung \\
\hline 6. & Bungkus & Bacang & $\begin{array}{l}\text { Daun } \\
\text { Hanjuang/Lipat }\end{array}$ & $\begin{array}{l}\text { Beras \& } \\
\text { daging }\end{array}$ \\
\hline 7. & Bungkus & Ketan & $\begin{array}{l}\text { Daun pisang \& } \\
\text { plastik/Lipat }\end{array}$ & Beras Ketan \\
\hline 8. & Bungkus & Ketan Muntilan & $\begin{array}{l}\text { Daun pisang \& } \\
\text { plastik/Lipat }\end{array}$ & Beras Ketan \\
\hline 9. & Bungkus & Lepet jagung & $\begin{array}{l}\text { Daun } \\
\text { Jagung/Gulung }\end{array}$ & Jagung \\
\hline 10. & Bungkus & Thiwul Ayu & $\begin{array}{l}\text { Daun pisang } \\
\text { /Lipat }\end{array}$ & Beras \\
\hline 11. & Bungkus & Jagung & Daun pisang/lipat & Jagung \\
\hline 12. & Urug & Ketupat Sayur & Janur/ dijalin & Beras \\
\hline 13. & Urug & Ketupat Sinto & Janur/ dijalin & Beras \\
\hline 14. & Urug & Kupat & Janur/jalin & Beras \\
\hline 15. & Alas & Ledre & Daun pisang & Beras Ketan \\
\hline 16. & Pasung & Pasung & $\begin{array}{l}\text { Daun } \\
\text { pisang/gulung }\end{array}$ & $\begin{array}{l}\text { Tepung } \\
\text { Beras } \\
\end{array}$ \\
\hline 17. & - & Lepet Ketan & Janur/lilit & Beras Ketan \\
\hline 18. & Jepit & Jadah Manten & $\begin{array}{l}\text { Bambu \& daun } \\
\text { pisang/jepit }\end{array}$ & $\begin{array}{l}\text { Beras ketan, } \\
\text { daging sapi, } \\
\text { telur }\end{array}$ \\
\hline
\end{tabular}

Melalui tabel jenis kemasan dalam makanan pokok yang berhasil dikumpulkan terdapat 6 jenis kemasan yang berasal dari 18 jenis makanan pokok. Jenis kemasan yang paling banyak digunakan yaitu kemasan pincuk dan bungkus. Selain itu terdapat kemasan urug, alas, pasung, dan jepit.

Tidak semua jenis kemasan dikenal dengan nama khas kemasan tersebut, seperti kemasan thiwul ayu hanya dikenal sebagai nama bungkusnya saja. Beberapa nama kemasan yang khas seperti tum untuk moto kebo, urug untuk jenis ketupat sayur dan ketupat sinto, jepit untuk jadah manten, dan jenis kemasan dengan nama pasung untuk makanan yang dikenal dengan nama pasung. 
Bahan kemasan dalam daftar makanan pokok terdiri dari daun pisang, janur, daun hanjuang, bambu, plastik, dan kertas. Plastik dan kertas merupakan material kemasan yang terimbas bahan modern.

Terdapat beberapa macam teknik mengemas seperti menjalin untuk membuat ketupat, menggulung untuk lepet, membungkus dengan melipat beberapa bagian untuk bacang, maupun teknik membungkus dengan cara menggulung.

Beberapa jenis kemasan tidak tampak nilai estetiknya justru karena digabungkan dengan kemasan kertas pada bagian luarnya. Kemasan makanan yang memperlihatkan nilai estetik karena bentuknya yang menarik tampak pada kemasan pasung yang berbentuk kerucut yang memperlihatkan pada bagian atas atau bagian isi kemasan,lepet jagung dengan kemasan berasal dari daun jagung, urug untuk ketupat, mendut ketan yang berbentuk kerucut.

Tabel 2 Jenis Kemasan Makanan dalam Makanan Penyerta Makanan Pokok (lauk pauk, sayuran, \& buah-buahan).

\begin{tabular}{|c|c|c|c|c|}
\hline No. & $\begin{array}{c}\text { Nama } \\
\text { Kemasan }\end{array}$ & $\begin{array}{c}\text { Nama } \\
\text { Makanan }\end{array}$ & $\begin{array}{c}\text { Bahan \& Teknik } \\
\text { Kemasan }\end{array}$ & $\begin{array}{c}\text { Bahan } \\
\text { Makanan }\end{array}$ \\
\hline 1. & Pincuk & Terancam & $\begin{array}{l}\text { Daun pisang \& kertas } \\
\text { /Lipat }\end{array}$ & $\begin{array}{l}\text { Sayuran \& } \\
\text { Kelapa Parut }\end{array}$ \\
\hline 2. & Pincuk & Metho & $\begin{array}{l}\text { Daun pisang } \\
\text { /Lipat/tum }\end{array}$ & $\begin{array}{l}\text { Tepung beras, } \\
\text { daging cincang }\end{array}$ \\
\hline 3. & Pincuk & Gudangan & $\begin{array}{l}\text { Daun pisang } \\
\text { /Lipat/tum }\end{array}$ & Sayuran \\
\hline 4. & Pincuk & Bothok & $\begin{array}{l}\text { Daun pisang } \\
\text { /Lipat/tum }\end{array}$ & $\begin{array}{l}\text { Kelapa, petai } \\
\text { selong }\end{array}$ \\
\hline 5. & Pincuk & Mie Basah & $\begin{array}{l}\text { Daun pisang \& kertas, } \\
\text { semat /Lipat }\end{array}$ & Tepung \\
\hline 6. & Bungkus & Lemper & $\begin{array}{l}\text { Daun pisang \& } \\
\text { kertas/digulung }\end{array}$ & Beras \\
\hline 7. & Bungkus & Lontong & $\begin{array}{l}\text { Daun pisang \& } \\
\text { semat/digulung }\end{array}$ & Beras \\
\hline 8. & Bungkus & Lego Moro & $\begin{array}{l}\text { Daun pisang \& } \\
\text { bambu/digulung }\end{array}$ & Beras ketan \\
\hline 9. & Bungkus & $\begin{array}{l}\text { Lamang } \\
\text { Tapai }\end{array}$ & $\begin{array}{l}\text { Daun pisang \& } \\
\text { bambu/digulung }\end{array}$ & Beras Ketan \\
\hline 10. & Bungkus & Ketan Bakar & $\begin{array}{l}\text { Daun pisang \& } \\
\text { bambu/lipat }\end{array}$ & Beras Ketan \\
\hline 11. & Bungkus & Pepes & $\begin{array}{l}\text { Daun pisang \& } \\
\text { bambu/digulung }\end{array}$ & Ikan \\
\hline 12. & Bungkus & Tempe I & $\begin{array}{l}\text { Daun pisang \& } \\
\text { bambu/digulung }\end{array}$ & Kacang kedele \\
\hline 13. & Bungkus & Tempe II & Daun pisang \& & Kacang kedele \\
\hline
\end{tabular}




\begin{tabular}{|c|l|l|l|l|}
\hline No. & \multicolumn{1}{|c|}{$\begin{array}{c}\text { Nama } \\
\text { Kemasan }\end{array}$} & $\begin{array}{c}\text { Nama } \\
\text { Makanan }\end{array}$ & $\begin{array}{c}\text { Bahan \& Teknik } \\
\text { Kemasan }\end{array}$ & \multicolumn{1}{|c|}{$\begin{array}{c}\text { Bahan } \\
\text { Makanan }\end{array}$} \\
\hline & & & bambu/digulung & \\
\hline 14. & Bungkus & Tempe Sangit & Daun pisang /Lipat & Kacang Kedele \\
\hline 15. & Kronjot & Pisang ambon & Bambu/anyam & Pisang ambon \\
\hline 16. & Keranjang & Gereh & Bambu/anyam & Ikan \\
\hline 17. & Tusuk & Sate Kecap & Bambu & Daging \\
\hline
\end{tabular}

Melalui tabel di atas, jenis kemasan dalam makanan penyerta makanan pokok seperti lauk pauk, sayuran, \& buah-buahan yang berhasil dikumpulkan terdapat 5 jenis kemasan makanan yang berasal dari 17 jenis makanan. Kemasan makanan yang paling banyak digunakan adalah kemasan pincuk dan bungkus. Jenis kemasan lainnya kronjot untuk buah-buahan, keranjang untuk gereh, dan tusuk untuk sate.

Nama-nama kemasan yang ada tidak semua jenis kemasan dikenal dengan nama khas kemasan tersebut. Misalnya kemasan pepes ikan hanya dikenal dengan istilah bungkus.Beberapa kemasan yang menggunakan nama khas seperti kronjot untuk jenis kemasan pembungkus pisang ambon.

Bahan kemasan dalam kelompok makanan ini terdiri dari daun pisang, bambu, dan kertas. Terdapat beberapa macam teknik mengemas seperti menggulung, untuk bungkusan pepes ikan maupun tempe, menjalin untuk kemasan krojot, pincuk untuk kemasan mie basah maupun bothok.

Kemasan makanan yang memperlihatkan nilai estetik karena bentuknya yang menarik tampak pada kemasan krojot dengan menjalin bilah-bilah bambu. Beberapa jenis kemasan tidak tampak nilai estetiknya justru karena digabungkan dengan kemasan kertas pada bagian luarnya.

Tabel 3 Jenis Kemasan Makanan dalam Makanan Jajanan.

\begin{tabular}{|c|l|l|l|l|}
\hline No. & Nama Kemasan & $\begin{array}{c}\text { Nama } \\
\text { Makanan }\end{array}$ & $\begin{array}{c}\text { Bahan \& Teknik } \\
\text { Kemasan }\end{array}$ & Bahan Makanan \\
\hline 1. & Pincuk & Pis Kopyor & Daun pisang /Lipat/tum & $\begin{array}{l}\text { Roti Tawar dan } \\
\text { kelapa }\end{array}$ \\
\hline 2. & Pincuk & Carang Gesing & Daun pisang /Lipat/ tum & $\begin{array}{l}\text { Pisang dan } \\
\text { Kelapa }\end{array}$ \\
\hline 3. & Pincuk & Getuk & $\begin{array}{l}\text { Daun pisang \& kertas } \\
\text { /Lipat/ tum }\end{array}$ & Ubi \\
\hline
\end{tabular}


Nilai Estetis pa da Kemasan Makanan Tradisiona I Yogyakarta 23

\begin{tabular}{|c|c|c|c|c|}
\hline No. & Nama Kemasan & $\begin{array}{c}\text { Nama } \\
\text { Makanan } \\
\end{array}$ & $\begin{array}{c}\text { Bahan \& Teknik } \\
\text { Kemasan }\end{array}$ & Bahan Makanan \\
\hline 4. & Pincuk & Kipo & $\begin{array}{l}\text { Daun pisang \& kertas } \\
\text { /Lipat }\end{array}$ & $\begin{array}{l}\text { Tepung Ketan, } \\
\text { enten-enten }\end{array}$ \\
\hline 5. & Pincuk & Monte & $\begin{array}{l}\text { Daun pisang \& kertas } \\
\text { /Lipat }\end{array}$ & $\begin{array}{l}\text { Tepung Ketan, } \\
\text { Kanji }\end{array}$ \\
\hline 6. & Pincuk & Nagasari II & $\begin{array}{l}\text { Daun pisang \& kertas } \\
\text { /Lipat/tum }\end{array}$ & Beras \& pisang \\
\hline 7. & Bungkus & Lopis & $\begin{array}{l}\text { Daun pisang \& kertas } \\
\text { /Lipat/tum }\end{array}$ & Beras Ketan \\
\hline 8. & Bungkus & Putuk Klepon & $\begin{array}{l}\text { Daun pisang \& kertas } \\
\text { /Lipat/tum }\end{array}$ & Tepung Beras \\
\hline 9. & Bungkus & Madusirat & $\begin{array}{l}\text { Daun pisang \& } \\
\text { /Lipat/tum }\end{array}$ & Beras Ketan \\
\hline 10. & Bungkus & Putu & $\begin{array}{l}\text { Daun pisang \& kertas } \\
\text { /Lipat/tum }\end{array}$ & Tepung beras \\
\hline 11. & Bungkus & Cenil & $\begin{array}{l}\text { Daun pisang \& kertas } \\
\text { /Lipat/tum }\end{array}$ & Kanji \\
\hline 12. & Bungkus & Tape Ketan & $\begin{array}{l}\text { Daun pisang \& kertas } \\
\text { /Lipat/tum }\end{array}$ & Beras Ketan \\
\hline 13. & Bungkus & Nagasari I & Daun pisang /Lipat & Beras \& pisang \\
\hline 14. & Kronjot & Ubi Arnet & Bambu/anyam & Ubi \\
\hline 15. & Besek & Tape Singkong & Bambu/anyam & Ketela \\
\hline 16. & & Bagea & Daun Nira/lipat & Nira \\
\hline 17. & Alas & Hoe & Daun Pisang & Tepung Beras \\
\hline
\end{tabular}

Melalui tabel di atas jenis kemasan makanan dalam makanan jajanan yang berhasil dikumpulkan terdapat 5 jenis kemasan makanan yang berasal dari 17 jenis makanan jajanan. Jenis makanan yang paling banyak digunakan adalah jenis pincuk dan bungkus, sedangkan jenis lainnya berupa kronjot, besek, dan alas hanya digunakan pada satu jenis makanan saja.

Nama-nama kemasan yang ada tidak semua jenis kemasan dikenal dengan nama khas kemasan tersebut. Misalnya kemasan naga sari I hanya dikenal dengan nama bungkus saja. Pada umumnya tidak ada penamaan khas untuk makanan jajanan kecuali ubi yang dikemas dalam keranjang jalinan bambu yang disebut dengan nama kronjot.

Bahan kemasan dalam daftar makanan pokok terdiri dari daun pisang, , bambu, daun nira, dan kertas. Kertas merupakan material kemasan yang terimbas bahan 
modern dan seringkali memperburuk kemasan tradisional yang terbuat dari bahan organik.

Terdapat beberapa macam teknik mengemas seperti menjalin untuk membuat ketupat, menggulung untuk lepet, membungkus dengan melipat beberapa bagian untuk bacang, maupun teknik membungkus dengan cara menggulung, serta teknik menganyam.

Jenis kemasan yang memperlihatkan nilai estetik dari cara mengemas maupun material yang digunakan adalah kemasan untuk makanan bagea yang menggunakan daun nira berwarna coklat tua yang dipadukan dengan semat dari lidi. Perpaduan warna antara warna makanan yang merah dan alas makanan dari daun berwarna hijau pada kue hoe memberikan kesan kontras yang menarik. Sebenarnya kemasan pincuk atau tum yang digunakan dalam mengemas jenis nagasari atau pada pis klepon cukup menarik jika melipat dengan rapih sehingga lipatan-lipatan daunnya terlihat tegas dan terjadi saling kontras dari alur tekstur daun.

\section{Simpulan}

Kemasan makanan tradisional memiliki nilai filosofis karena makanan tradisional tertentu erat kaitannya dengan kegiatan upacara dalam masyarakat Yogyakarta. Kemasan makanan dan makanannya digunakan sebagai simbol tertentu dalam sebuah upacara Kraton maupun upacara yang berkaitan dengan siklus hidup masyarakat di Yogyakarta.

Nilai filosofis yang menjadi bagian dari budaya Jawa tersebut tidak dapat dipisahkan dari falsafah hidup orang Jawa secara keseluruhan. Baik nilai yang berkembang di lingkungan keraton, maupun nilai filosofis yang berkembang di lingkungan masyarakat kebanyakan.

Nilai estetik kemasan makanan tradisional dapat terlihat dari proses pembuatannya seperti terlihat pada teknik anyaman untuk grojot dan urug, atau lipatan pada pincuk, maupun kontras antara warna kemasan dengan makanannya. Kesemua bentuk visual kemasan makanan umumnya bersifat alami dan menyatu dengan kehidupan tradisi masyarakat Yogya. Nilai estetik pada kemasan tradisional seringkali mengalami penurunan makna justru karena dipadukan dengan kemasan modern seperti kertas dan plastik.

\section{Daftar Pustaka}

[1] Agoes, A. 2001. Kiat Sukses Menyelenggarakan Pesta Perkawinan Adat Jawa: Gaya Surakarta \& Yogyakarta, Gramedia Pustaka Utama, Jakarta. 
[2] Bratawidjaja, T.W. 2000. Upacara Tradisional Masyarakat Jawa, Pustaka Sinar Harapan, Jakarta.

[3] F.G. Winarno, ed. 1999. Kumpulan Makanan Tradisional I, Pusat Kajian Makanan Tradisional Perguruan Tinggi Departemen Pendidikan dan Kebudayaan, Jakarta.

[4] Fox, J.J. ed. 1998. Indonesian Heritage: Religion and Ritual, Archipelago Press, Singapore.

[5] Hari, S. 2002. Alamanak Yogyakarta: Yogyakarta Handbook, Lintang Mataram, Yogyakarta.

[6] Pringgawidagda, S. Paningset. 2003. Srah-srahan \& Midodareni, Adicita Yogyakarta. 2003. Siraman, Adicita Yogyakarta.

[8] 2003. Upacara Tingkeban, Adicita Yogyakarta.

[9] Suratno, C. ed. 2002. Kraton Jogja: The History and Cultural Heritage, Kraton Ngayogyakarta Hadiningrat and Indoensia Marketing Association (IMA), Jakarta.

[10] Sunaryo, E. 1997. Wujud dan Makna Perlambangan Gunungan Garebeg dalam Budaya Keraton Yogyakarta, Tesis, FSRD ITB, hal. 133.

\section{Sumber Dana Penelitian}

[1] Diperoleh melalui kompetisi BOGASARI NUGRAHA VI - 2003.

[2] Kajian Aspek Sosial Budaya.

[3] Kelompok Dosen. 